$\xi=$ 不

\title{
Petro physical properties analysis of beani bazar gas field, Bangladesh using wireline log interpretation
}

\author{
G. M. Ariful Islam, Farzana Yeasmin Nipa*, Md. Shaheen Shah \\ Department of Petroleum and Mining Engineering, Jessore University of Science and Technology, Jessore-7408, Bangladesh \\ *Corresponding author E-mail: n.jstu@yahoo.com
}

\begin{abstract}
The study on analysis of petro physical properties which are done into two well such as BB-1 and BB-2 of Beani Bazar Gas Field using wire line log data. In BB-1, Upper Gas Sand (UGS), Lower Gas Sand (LGS), Sand-1 and Bellow Lower Gas Sand (BLGS) zones and in BB-2, UGS and LGS are identified through high gamma ray log, high resistivity, low neutron and low density log response. The thickness of UGS, LGS, Sand-1, BLGS of BB-1 and UGS, LGS of BB-2 are respectively $47.69 \mathrm{~m}, 14.326 \mathrm{~m}, 17.526 \mathrm{~m}, 17.526 \mathrm{~m}$ and $26.37 \mathrm{~m}$, $21.03 \mathrm{~m}$. The Shale volumes of UGS, LGS, Sand-1 and BLGS of BB-1 are respectively $14.87 \%, 21.58 \%, 11.69 \%$ and $21.28 \%$ and UGS and LGS of BB-2 are respectively $17.91 \%$ and $29.33 \%$, which are measured through Schlumberger Clavier method. The average porosity of UGS, LGS, Sand-1 and BLGS of BB-1 are respectively 17.55\%, 16.60\%, 18.07\% and 31.10\% and UGS and LGS of BB-2 are respectively $13.19 \%$ and $11.29 \%$, which are very effective for hydrocarbon prospect by using neutron-density combination method. The average water saturations of UGS, LGS, Sand-1 and BLGS of BB-1 are respectively $24.97 \%, 23.78 \%, 80.18 \%$ and $19.85 \%$ which revised to hydrocarbon saturations as respectively $75.03 \%, 76.22 \%, 19.82 \%$ and $80.15 \%$ and UGS and LGS of BB-2 are respectively $41.20 \%$ and $69.50 \%$ which revised to hydrocarbon saturations as respectively $58.80 \%$ and $30.50 \%$ that are followed by Simandoux method. By analysis of petro physical properties of those zones, the UGS and LGS are very effective hydrocarbon bearing zones where production is running at the present time, the Sand-1 zone is water bearing zone. This study impose high important on BLGS. This zone is satisfied all criteria for hydrocarbon prospect. This study recommends that more study is needed for BLGS, and it may be commercially economical viable in a future.
\end{abstract}

Keywords: Hydrocarbon Saturation; Beani Bazar Gas Field; Petro physical Properties; Hydrocarbon Prospect and Wireline Log Data.

\section{Introduction}

Wireline logging is the practice of making a detailed record of the geologic formations penetrated by the well. Petro physical properties are the properties of a reservoir such as thickness, lithology, shale volume, porosity, water saturation and hydrocarbon saturation of the gas field (Ajisafe \& Ako, 2013). Different types of gamma ray (GR), spontaneous potential (SP), resistivity, neutron and density $\log$ are determined to the petro physical characteristics of the reservoirs such as porosity, hydrocarbon saturation and water saturation (Asquith \& Gibson, 1982). The proposed study aims at interpretation of well $\log$ data and quantitative evaluation of petro physical properties such as water saturation, shale volume, sand thickness, porosity, water resistivity, geothermal gradient, formation temperature etc. in a Beani Bazar gas field, well-1 and well-2. Beani Bazar Gas Field Well-1 (BB-1) was discovered by Parker Drilling Company (PDC), Germany at 1979. This well was spudded in on 20th November 1980, and the drilling was completed on $12^{\text {th }}$ may 1981 . The total depth (TD) reached at 13480 feet (4108.70m).Beani Bazar Well-2 (BB-2) was drilled under the second Gas Development Project (SGDP). The well was spudded in on $21^{\text {st }}$ March 1988 , and the drilling was completed on $16^{\text {th }}$ July1988 at a total depth (TD) reached at 13,480 feet (4108.70m). The study area is a Beani Bazar gas field (Fig. 1) which is located in Beani Bazar upazila of Sylhet District in the division of Sylhet, Bangladesh. The well Beanibazar-1 is located at $92^{\circ} 10^{\prime} 18^{\prime \prime} \mathrm{N}$ and $24^{\circ} 97^{\prime} 33^{\prime \prime} \mathrm{E}$ and Beanibazar-2 is located at $92^{\circ} 10^{\prime} 9.99^{\prime \prime} \mathrm{N}$ and $24^{\circ} 48^{\prime 2} 249^{\prime \prime}$ E. The main objectives of this research of well log analysis are to measure the petro physical properties of the Beani Bazar Gas field to detect prospective hydrocarbon zone.

\section{Geological structure of beani bazar gas field}

Beani Bazar structure is situated within the folded flank of the Bengal fore deep. The structure lies on the Western margin of the Chittagong-Tripura folded belt in the south-central part of the Surma Basin. On the surface, the structure has a north south extension of about $12 \mathrm{~km}$ and $7 \mathrm{~km}$ wide. The dips of the flanks are symmetrical, and the amplitude is gradually decreasing with an increase of depth. In the upper horizon, dips are low $\left(2^{0}-3^{0}\right)$ but in the deeper horizon this increases slightly and amounts to $\left(8^{0}-11^{0}\right)$. The northern pitch is steeper than the south. The top of the upper pay zone was delineated by a contour line of $3200 \mathrm{~m}$ and the crest is found about $500 \mathrm{~m} \mathrm{NNW}$ of well no.1.The dimension of the structure on top of the upper pay zone is $11 \mathrm{~km} \times 5 \mathrm{~km}$ (within closed contour $3400 \mathrm{~m}$ ), and the amplitude is about $200 \mathrm{~m}$. The dimension of the structure on top of the lower pay zone does not change much. But the crest of the lower zone is slightly shifted towards SSE, and the well is almost on the top. No faults were observed from the 2D seismic data over the Beani Bazar structure, or it's about. This is probably due to the low resolution of the variable quality $2 \mathrm{D}$ seismic data and probably more faults can be expected to be seen in a higher resolution $3 \mathrm{D}$ seismic data set. 


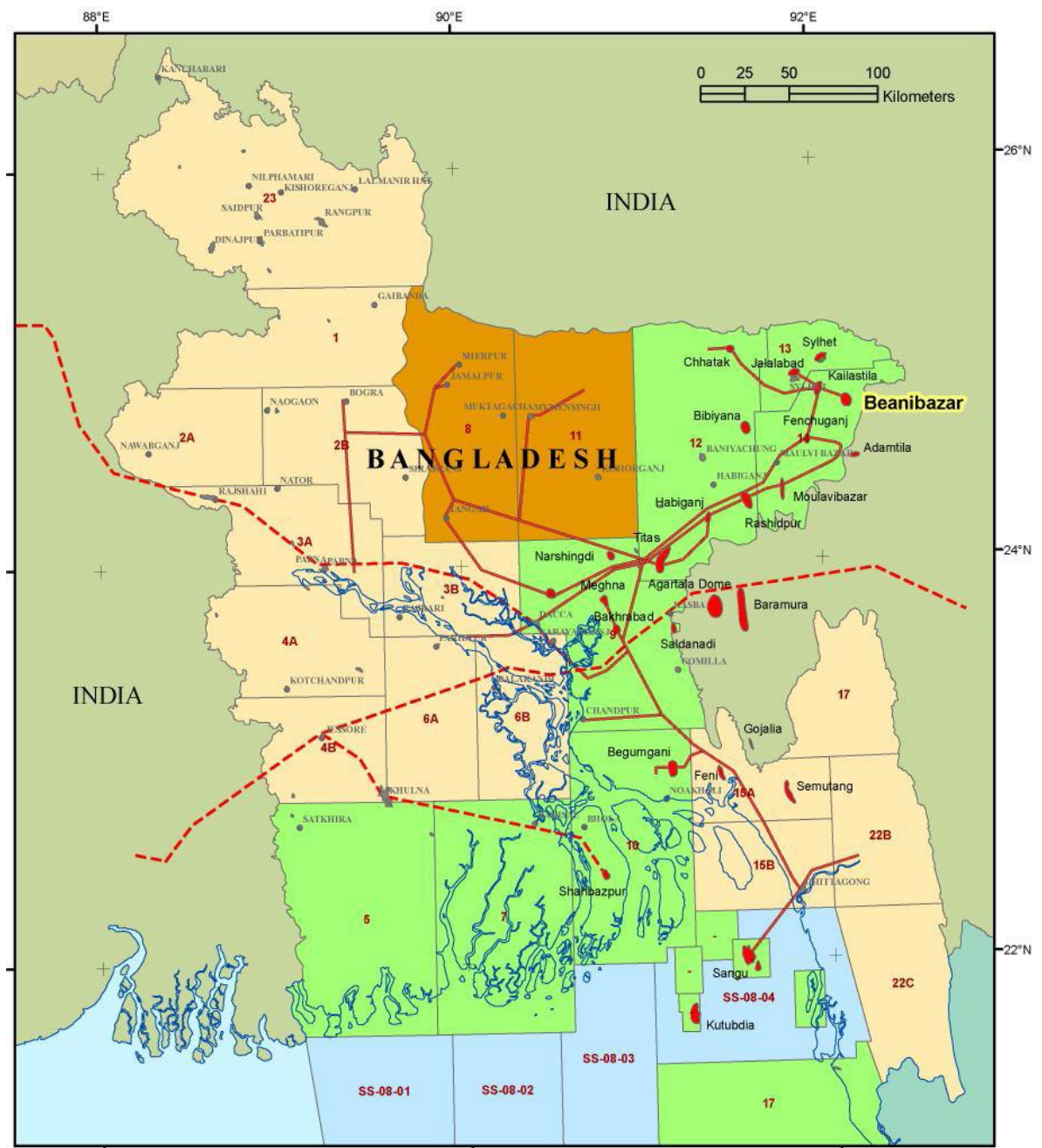

Fig.1: Location Map of Beani Bazar Gas Field (Source: RPS Energy Report, Petrobangla).

\section{Methodology}

The study is mainly based on the petro physical properties of Beani Bazar gas field well no. 1 and 2. The value of the wire-line $\log$ data is plotted continuously against depth in the well. Wireline $\log$ data is the most consistent source of information for determining the presence of hydrocarbon. For this research purposes, Resistivity (R) log, Gamma ray (GR) log, Neutron log and Density $\log$ are used to determine the petro physical properties of Beani Bazar gas field. The steps for determination of petro physical properties of the Beani Bazar gas field are as follows:

\subsection{Lithology identification}

The natural radioactivity of the formations in the borehole on the gamma ray (GR) log is identifying lithology (Hasan et al. 2013). High GR value indicates shale due to the presence of potassium ions in the lattice structure of clay mineral and low GR value exhibit reservoir rock (sandstone) due to the absence of potassium ions in the lattice structure of minerals (Asquith \& Gibson, 1982).

\subsection{Shale volume calculation}

At initial situation, through gamma ray log value, shale volume can be calculated by using gamma ray index $\left(\mathrm{I}_{\mathrm{GR}}\right)$ for tertiary rocks (Schlumberger, 1972)

That's given bellow:

$I_{G R}=\left\lfloor\left(G R_{\mathrm{log}}-G R_{\min }\right) /\left(G R_{\max }-G R_{\min }\right)\right\rfloor$
Where, $\quad I_{G R}=$ Gamma ray index, $G R_{\log }=$ Gamma ray response in the zone of interest, $\boldsymbol{G} \boldsymbol{R}_{\min }=$ Minimum gamma ray response in clean, shale free formation and $G \boldsymbol{R}_{\max }=$ Maximum gamma ray response in shale zone.

Various formulas are used to modify the linearly derived shale volume to obtain a more satisfying answer. The Dresser Atlas's equation (Atlas, 1979) is used for measuring shale volume. This equation given bellow:

$$
V_{s h}=0.083\left[2^{3.7 \times I_{G R}}-1.0\right]
$$

\subsection{Porosity calculation}

After determining the volume of shale, porosity is calculated from density-neutron logs (Schlumberger, 1979). The porosity equation (Atlas, 1979) from density log consists of matrix density, fluid density, bulk density. This Equation is given bellow:

$$
\phi_{d}=\left(\frac{\rho_{m a}-\rho_{b}}{\rho_{m a}-\rho_{f}}\right)-V_{s h}\left(\frac{\rho_{m a}-\rho_{s h}}{\rho_{m a}-\rho_{f}}\right)
$$

Where, $\phi_{d}=$ The density porosity, $\rho_{m a}=$ Matrix density $(\mathrm{gm} / \mathrm{cc}), \quad \rho_{b}=$ Bulk density, $\quad \rho_{f}=$ Fluid density and $\rho_{s h}=$ Shale density.

The porosity is measured by neutron log through following equation (Atlas, 1979), the clay corrected Neutron porosity,

$\phi_{n-c o r r}=N P H I-\left(V_{s h} * N P H I_{s h}\right)+$ Litholog yCorrection 
Where, $N P H I=$ Neutron $\operatorname{logs}$ value of zone of interest, $N P H I_{s h}=$ Average neutron log value of shale volume and $\mathrm{Li}-$ thology correction $=0.04$.

It is always best to read porosities directly from the logs where the lithological units match the formation lithology. To obtain correct porosities from density-neutron logs using Schlumberger (Schlumberger, 1979) when the two logs record different porosities for a zone, use one of the methods given bellow:

$\phi=\sqrt{\left(\phi_{n}^{2}+\phi_{d}^{2}\right) / 2}$

Where, $\phi=$ The percent of porosity, $\phi_{n}=$ Neutron porosity and $\phi_{d}=$ Density porosity.

\subsection{Water saturation calculation}

The water saturation determined after the log-derived porosity had corrected for shale. The saturation is known as the total water saturation if the pore space is the total porosity, but is known as effective water saturation if the pore space is the effective porosity. In this research water saturation will be shown through Simandoux method. According to Simandoux method, the water saturation equation (Simandoux, 1963) given bellow:

$$
S_{w}=\left(\frac{0.4 \times R_{w}}{\phi^{2}}\right)\left[\frac{V_{s h}}{R_{s h}} \sqrt{\left(\frac{V_{s h}}{R_{s h}}\right)^{2}+\frac{5 \phi^{2}}{R_{t} \times R_{w}}}\right]
$$

Where, $S_{w}=$ Water saturation, $R_{w}=$ Formation water resistivity, $\phi=$ Porosity, $V_{s h}=$ Shale volume, $\boldsymbol{R}_{s h}=$ Resistivity of shale volume and $R_{t}=$ True resistivity.

\subsection{Hydrocarbon saturation calculation}

The percentage of total volume in a formation held by hydrocarbon is known as hydrocarbon saturation (Ahammod et al. 2014). It can be determined by the following equation:

$$
S_{h c}=100-S_{w}
$$

\section{Result}

Data are collected from log sheet which is provided by Petrobangla. Data are collected in two steps. Average log values are collected in first step where depth is in range such as $3230 \mathrm{~m}$ to $3277 \mathrm{~m}$ provides a single $\log$ value of different type of $\log$ (Fig. 2 and Fig. 3).

\subsection{Lithology and thickness identification}

From Wireline log observation, hydrocarbon prospective zones for Beani Bazar Gas Field BB-1 and BB-2 with respect to depth are shown on table 1 given bellow:

\begin{tabular}{lllll}
\multicolumn{5}{c}{ Table 1: Hydrocarbon Prospective Zones of Beani Bazar Gas Field. } \\
Well & Lithology & Depth $(\mathrm{m})$ & & Thickness $(\mathrm{m})$ \\
& & Top & Base & \\
& UGS & 3230.118 & 3277.81 & 47.69 \\
BB-1 & LGS & 3451.098 & 3465.424 & 14.326 \\
& Sand-1 & 3572.561 & 3590.087 & 17.526 \\
& BLGS & 3768.242 & 3781.806 & 13.56 \\
BB-2 & UGS & 3286.96 & 3313.328 & 26.37 \\
& LGS & 3496.056 & 3517.087 & 21.03
\end{tabular}

\subsection{Shale volume evaluation}

Shale volume $\left(\mathrm{V}_{\mathrm{sh}}\right)$ has been estimated from gamma ray log. Using those equations ( 1 and 2 ), the study can show shale volume content in selective zones of Beani Bazar gas field is given below as:

Table 2: Shale Volume of Beani Bazar Gas Field.

\begin{tabular}{llll}
\hline Zones & Depth $(\mathrm{m})$ & Average $\mathrm{V}_{\text {sh }}$ (fraction) & Average $\mathrm{V}_{\text {sh }}(\%)$ \\
\hline BB-1 & & & \\
UGS & $3230-3278$ & 0.1487 & 14.87 \\
LGS & $3452-3466$ & 0.2158 & 21.58 \\
Sand-1 & $3573-3590$ & 0.1169 & 11.69 \\
BLGS & $3768-3782$ & 0.2128 & 21.28 \\
BB-2 & & & \\
UGS & $3287-3313$ & 0.1791 & 17.91 \\
LGS & $3496-3517$ & 0.2933 & 29.33 \\
\hline
\end{tabular}

\subsection{Porosity distribution}

Porosity determination is a very important for analyzing the petro physical properties of any gas field (Ruhovets, 1990). Using equations (3, 4 and 5), calculate the average porosity of Beani Bazar Gas field both well. Those are given bellow:

Table 3: Porosity of Beani Bazar Gas Field

\begin{tabular}{llll}
\multicolumn{4}{c}{ Table 3: Porosity of Beani Bazar Gas Field. } \\
\hline Zones & Depth $(\mathrm{m})$ & $\varnothing$-Average (fraction) & $\varnothing$-Average (\%) \\
\hline BB-1 & & & \\
UGS & $3230-3278$ & 0.1755 & 17.55 \\
LGS & $3452-3466$ & 0.1660 & 16.60 \\
Sand-1 & $3573-3590$ & 0.1807 & 18.07 \\
BLGS & $3768-3782$ & 0.3110 & 31.10 \\
BB-2 & & & \\
UGS & $3287-3313$ & 0.1319 & 13.19 \\
LGS & $3496-3517$ & 0.1129 & 11.29 \\
\hline
\end{tabular}

\subsection{Water saturation calculation}

Water saturation is very important for knowing gas saturation in any gas field.

Water saturation is calculated through simandoux equation (6) which is shown on below:

Table 4: Water Saturation of Beani Bazar Gas Field

\begin{tabular}{llll}
\hline Zones & Depth $(\mathrm{m})$ & Sw-Average (fraction) & Sw-Average $(\%)$ \\
\hline BB-1 & & & \\
UGS & $3230-3278$ & 0.2497 & 24.97 \\
LGS & $3452-3466$ & 0.2378 & 23.78 \\
Sand-1 & $3573-3590$ & 0.8018 & 80.18 \\
BLGS & $3768-3782$ & 0.1985 & 19.85 \\
BB-2 & & & \\
UGS & $3287-3313$ & 0.4120 & 41.20 \\
LGS & $3496-3517$ & 0.6950 & 69.50 \\
\hline
\end{tabular}

\subsection{Hydrocarbon saturation measurement}

Hydrocarbon saturation is vital role for reserving gas in gas well. Equation (7) is reliable to calculate hydrocarbon saturation. According to Equation (7), the hydrocarbon saturation of Beani Bazar Gas field are given below:

Table 5: Hydrocarbon Saturation of Beani Bazar Gas Field

\begin{tabular}{llll}
\hline Zones & Depth $(\mathrm{m})$ & $\mathrm{S}_{\mathrm{HC}}-$ Average (fraction) & $\mathrm{S}_{\mathrm{HC}}$-Average $(\%)$ \\
\hline BB-1 & & & \\
UGS & $3230-3278$ & 0.7503 & 75.03 \\
LGS & $3452-3466$ & 0.7622 & 76.22 \\
Sand-1 & $3573-3590$ & 0.1982 & 19.82 \\
BLGS & $3768-3782$ & 0.8015 & 80.15 \\
BB-2 & & & \\
UGS & $3287-3313$ & 0.5880 & 58.80 \\
LGS & $3496-3517$ & 0.3050 & 30.50 \\
\hline
\end{tabular}




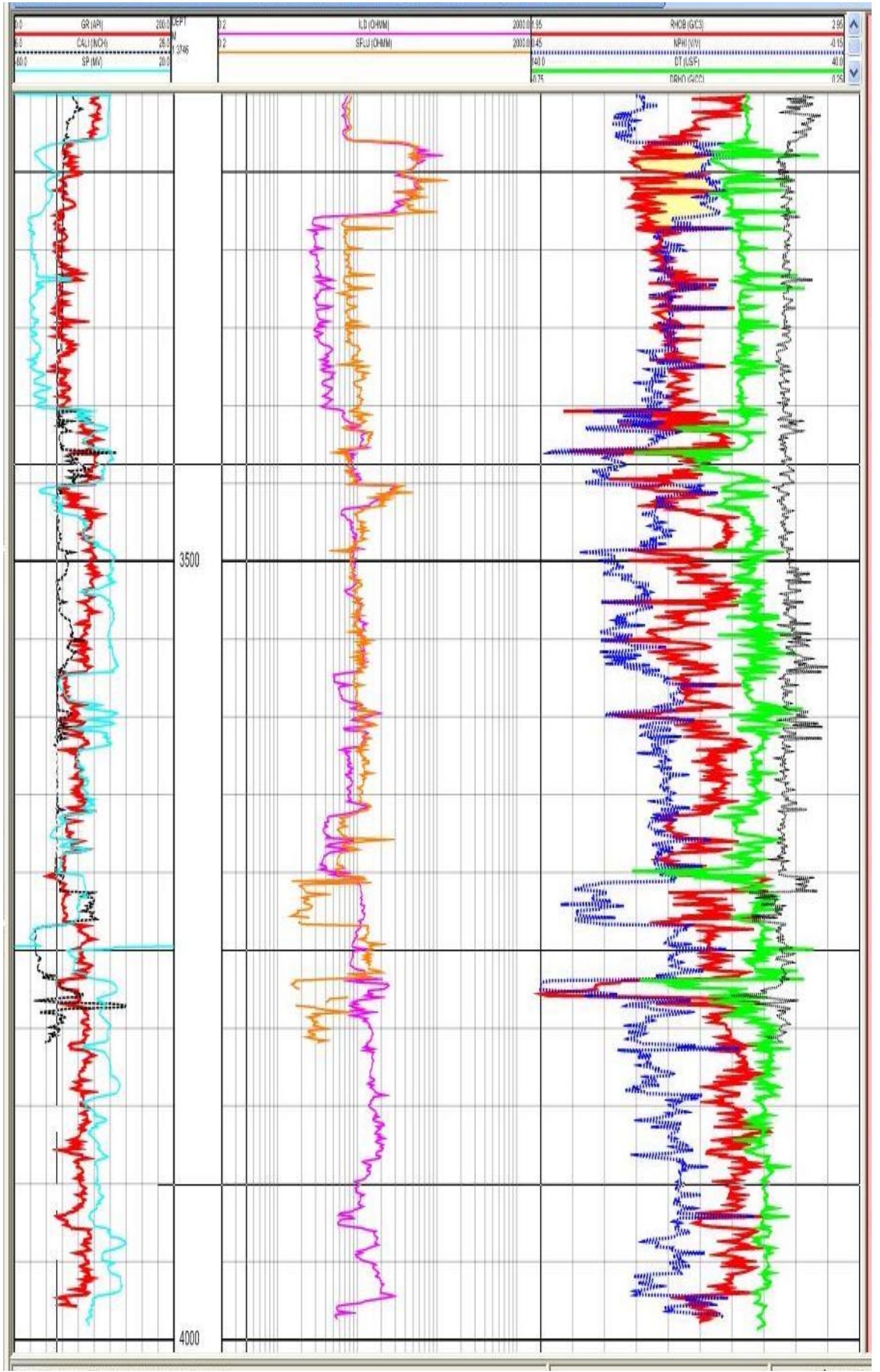

Fig. 2: Wireline log sheet of BB-1 of Beani Bazar Gas Field. 


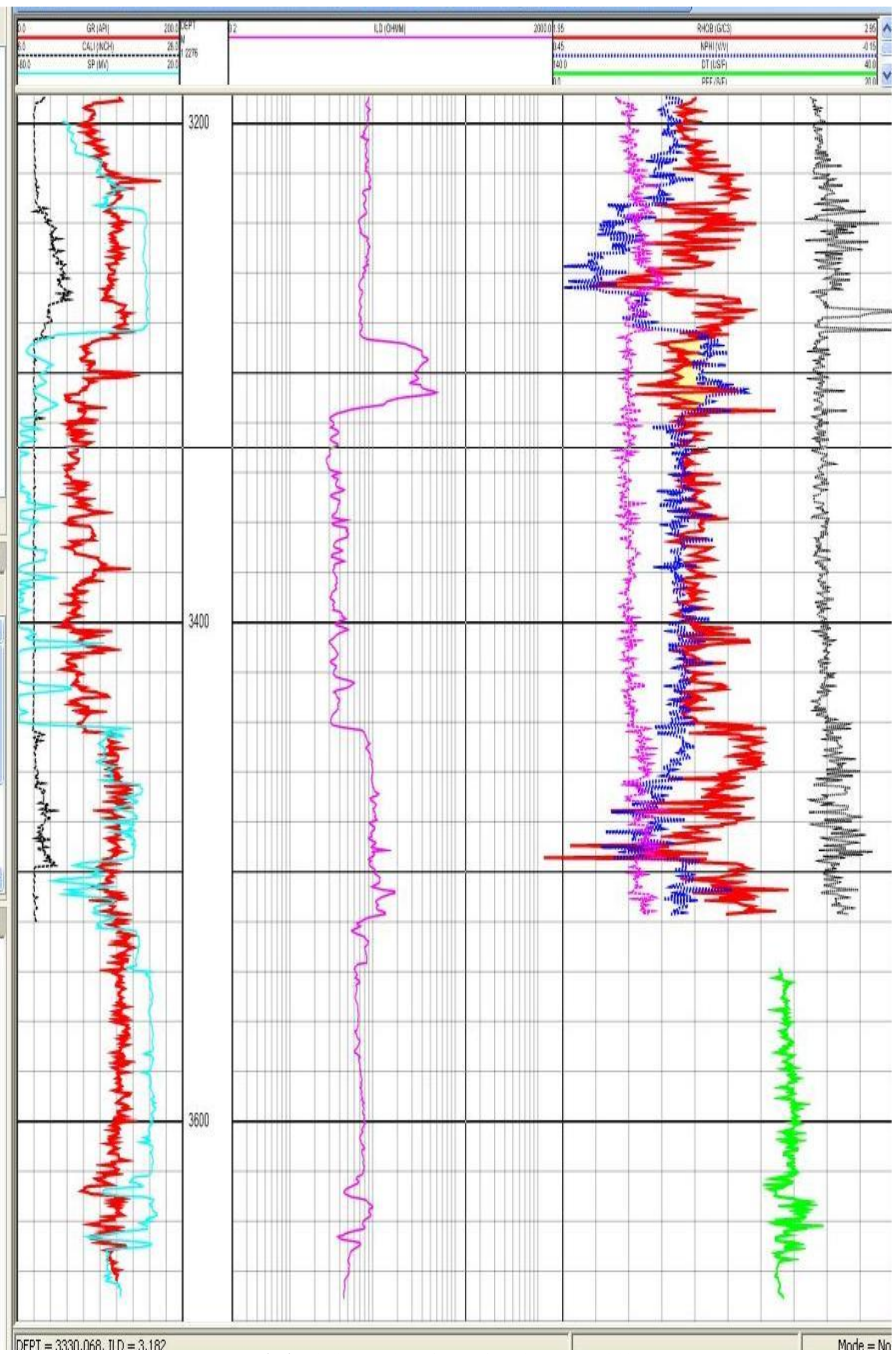

Fig. 3: Wireline Log sheet of BB-2 of Beani Bazar Gas Field. 


\section{Discussions}

The quantitative analysis of wireline log data evaluates the petrophysical properties (such as lithology, shale volume, porosity, water saturation and hydrocarbon saturation) of Beani Bazar Gas field. Hydrocarbon bearing zones are defined by the help of high resistivity, high SP, low GR values (Asquith \& Gibson, 1982), low density and neutron values (Fertl, 1987). In Beani Bazar Gas field well-1 (BB-1), four hydrocarbon bearing zones were identified. The depth range of hydrocarbon bearing zones (Fig. 4) as Upper Gas Sand (UGS) is 3230.118-3402.5 m, Sand Zone (sand-1) is $3572.561-3590.087 \mathrm{~m}$, Lower Gas Sand (LGS) is 3451.098$3465.424 \mathrm{~m}$ and Bellow Lower Gas Sand (BLGS) is 3768.242 $3781.806 \mathrm{~m}$ having thickness $172.382 \mathrm{~m}, 17.526 \mathrm{~m}, 14.326 \mathrm{~m}$ and $13.564 \mathrm{~m}$ respectively. Though the UGS thickness is $172.382 \mathrm{~m}$, but its Gas content thickness is $47.701 \mathrm{~m}$ at depth 3230.118 $3277.819 \mathrm{~m}$ and $124.681 \mathrm{~m}$ are fully water saturated. For that reasons the petrophysical properties of UGS in BB-1 are shown at depth 3230.118-3277.819 m.

In the Beani Bazar Gas field well-2 (BB-2), two hydrocarbon bearing zones were identified. The depth range of hydrocarbon bearing zones (Fig. 4) as Upper Gas Sand (UGS) is 3286.963$3313.328 \mathrm{~m}$ and Lower Gas Sand (LGS) is 3496.056-3517.087 m having thickness $26.365 \mathrm{~m}$ and $21.031 \mathrm{~m}$ respectively.

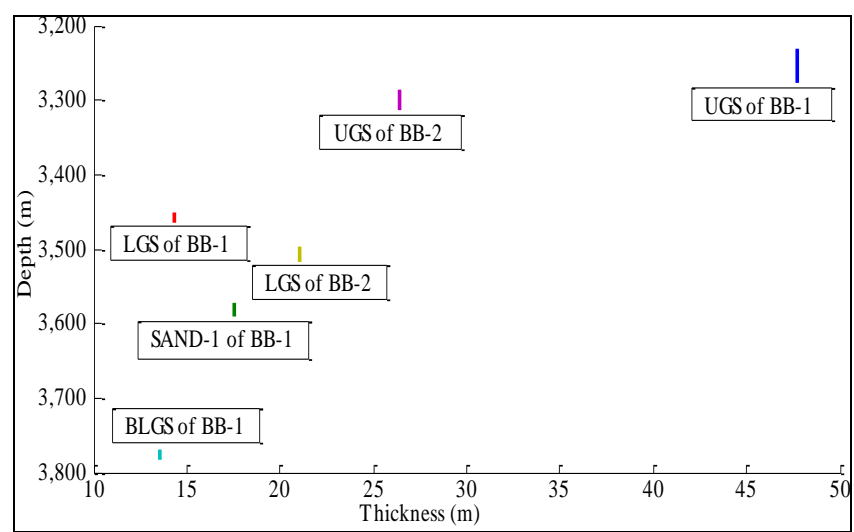

Fig. 4: Thickness of UGS, LGS, Sand-1, BLGS of BB-1 and UGS, LGS of BB-2.

The UGS hydrocarbon productive thickness of both BB-1 and BB2 is greater than all of others sand zones thickness.

The average shale volume of UGS, Sand-1, LGS and BLGS of BB-1 are respectively $14.67 \%, 11.69 \%, 21.58 \%$ and $21.28 \%$ (Fig. 5) which show that sand volume respectively $87.03 \%, 88.31 \%$, $78.42 \%$ and $78.72 \%$. UGS, LGS, Sand- 1 and BLGS of BB-1 are denoted as Shaly-Sand lithology (Islam \& Islam, 2014).

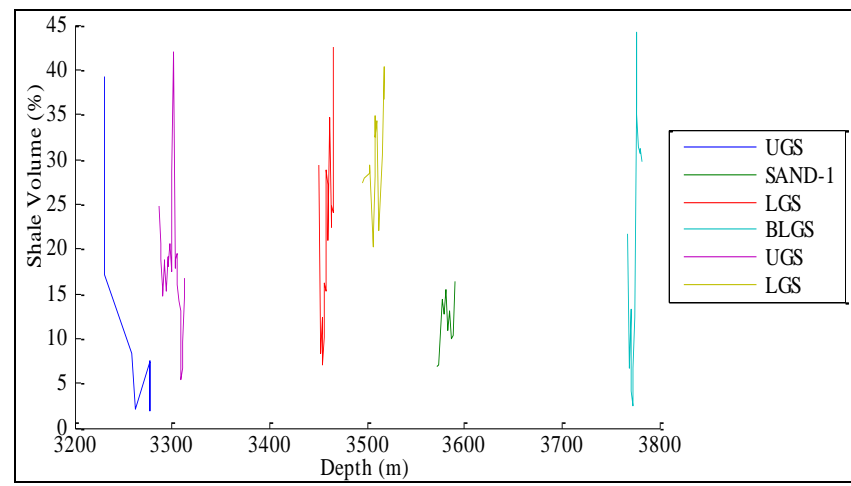

Fig. 5: Shale volume of UGS, LGS, SAND-1, BLGS of BB-1 and UGS LGS of BB-2.
And the average shale volumes of UGS and LGS of BB-2 are respectively $17.91 \%$ and $29.33 \%$ (Fig. 5) which show that sand volume respectively $82.09 \%$ and $70.67 \%$. That means all zones are indication of good quality sand (Eze et al. 2013).

Porosity determination is a vital important for estimating fluid saturation in the reservoir characterization (Ruhovets, 1990). The average porosity (Fig. 6) of UGS, Sand-1, LGS and BLGS of BB1 are respectively $17.55 \%, 18.07 \%, 16.60 \%$ and $31.10 \%$, which refers good porosity of these respective zones. And the average porosity (Fig. 6) of UGS and LGS of BB-2 are respectively $13.19 \%$ and $11.29 \%$, which refers good porosity of these respective zones. Like observation of average porosity values ranged are found in the Laja Oil Field, Rickie Field, KN Field and Y Field, Niger delta (Ajisafe \& Ako, 2013, Amigun et al. 2012, Richardson, 2013, Adeoti et al. 2014).

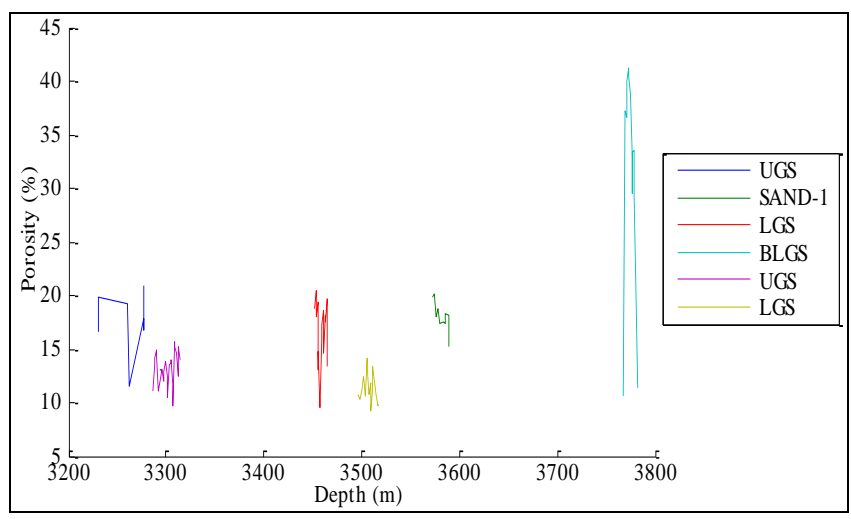

Fig. 6: Porosity of UGS, LGS, SAND-1, BLGS of BB-1 and UGS, LGS of BB-2.

The porosity of BLGS zones of BB-1 is greater than the other zones of BB-1 and BB-2.

The average water saturation (Fig. 7) of UGS, Sand-1, LGS and BLGS of BB-1 are estimated as respectively $24.97 \%$, $80.18 \%$, $23.78 \%$ and $19.85 \%$, which revised to hydrocarbon saturation (Fig. 8 ) as respectively $75.03 \%, 19.82 \%, 76.22 \%$ and $80.15 \%$. And the average water saturation (Fig. 7) of UGS and LGS of BB-2 are respectively $41.20 \%$ and $69.50 \%$, which revised to hydrocarbon saturation (Fig. 8) as respectively $58.80 \%$ and $30.50 \%$. The hydrocarbon saturation value exceeds $60 \%$ which indicates that the reservoir is productive (Asquith \& Gibson, 1982). Similar observations are made by Islam et al., (Islam et al.2009, Islam, 2010) in Bengal Basin.

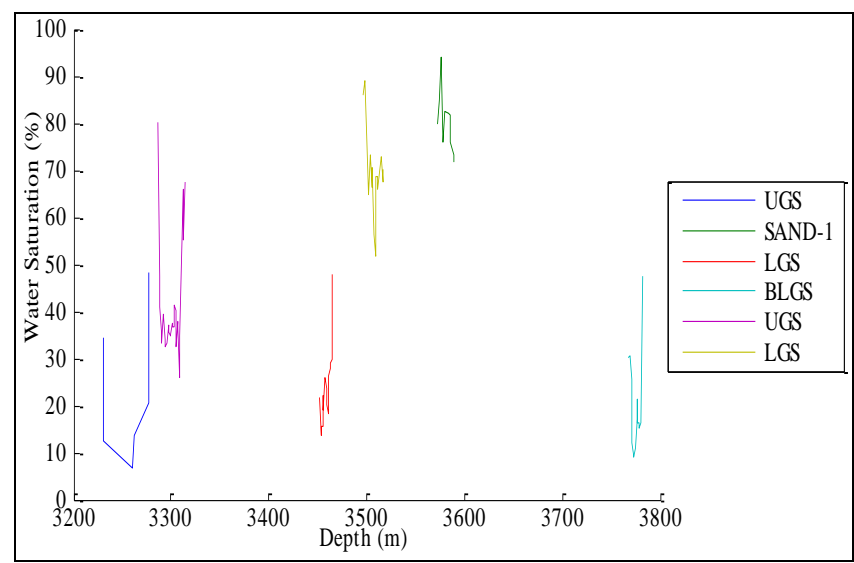

Fig. 7: Water saturation of UGS, LGS, SAND-1, BLGS of BB-1 and UGS, LGS of BB-2.

From this above study mentioned that the petro physical properties of Below Lower Gas Sand of Beani Bazar Gas field as thickness is $13.564 \mathrm{~m}$, average shale volume is $21.28 \%$ which show that sand volume is $78.72 \%$, average porosity is $31.10 \%$, average water 
saturation are estimated as $19.85 \%$ which revised to hydrocarbon saturation as $80.15 \%$.

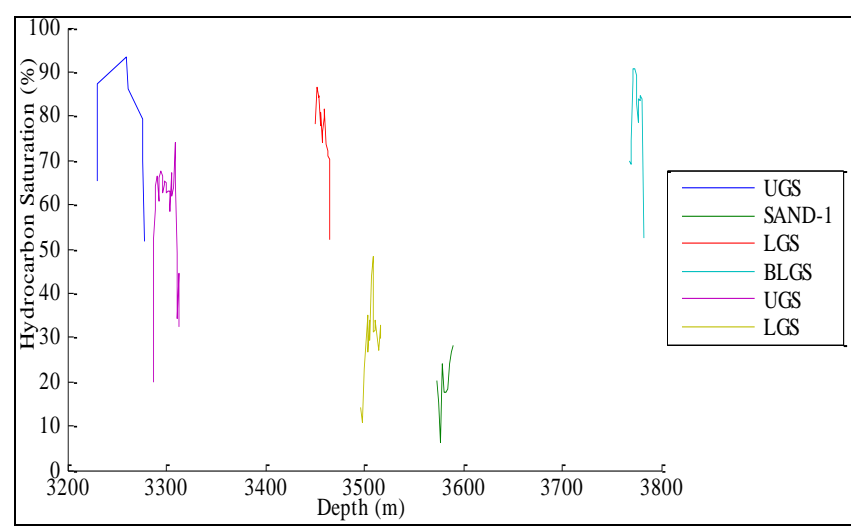

Fig. 8: Hydrocarbon saturation of UGS, LGS, SAND-1, BLGS of BB-1 and UGS, LGS of BB-2.

Below Lower Gas Sand of Beani Bazar Gas field is very significance zone which may be commercially hydrocarbon prospective in future. This zone is still now undiscovered. So this study will be very effective for this zone.

\section{Conclusions}

The reservoir efficiency analysis of the Beani Bazar Gas Field were obtained by using well logs such as GR log, resistivity $\log$, neutron $\log$ and density $\log$. Six hydrocarbon bearing zones were defined in the Beani Bazar Gas field (BB-1 and B B - 2) on the basis of composite log responses. The four zones in BB-1 are Upper Gas Sand (UGS), Lower Gas Sand (LGS), Sand-1 and Bellow Lower Gas Sand (BLGS), and the two zones in BB-2 are Upper Gas Sand and Lower Gas Sand. The gas reservoirs of Beani Bazar Gas field are demonstrated an average shale volume of about $19.44 \%$, average porosity $17.97 \%$, average water saturation $43.25 \%$, and average hydrocarbon saturation $56.75 \%$. All these measured parameters indicate that these reservoirs are good quality.The Upper Gas Sand and Lower Gas Sand of both BB-1 and BB-2 are producing gas in the present time. The Sand- 1 zone of BB-1 contains an average clay volume of about $11.69 \%$, average porosity $18.07 \%$, average water saturation $80.18 \%$ and average hydrocarbon saturation $19.82 \%$. The amount of water saturation is excessively high, which refers that, this zone is water bearing zone. The BLGS zone is very significant part of this study. This zone is shown an average clay volume $21.28 \%$, average porosity $31.10 \%$, average water saturation is $19.85 \%$ and average hydrocarbon saturation $80.15 \%$. After analysis the petrophysical properties of BLGS, it is found that, this zone can be hydrocarbon prospective in near future. The study recommended that specific in-depth study (i.e., 3D Seismic Survey) is needed to depict the real picture in a BLGS zone subsurface of Beani Bazar Gas field.

\section{Acknowledgements}

We are highly thankful to the Chairman of Bangladesh Oil, Gas and Mineral Corporation (Petrobangla) for their required approval and kind permission to provide necessary facilities while conducting this research. Thanks are also due for the individuals who helped during analysis.

\section{References}

[1] Ajisafe, Y.C.\&Ako, B.D. (2013), 3-D Seismic Attributes for Reservoir Characterization of "Y" Field Niger Delta, Nigria.IOSR Journal of Applied Geology and Geophysics,1(2), pp.2331.https://doi.org/10.9790/0990-0122331.
[2] Asquith, G.B.\& Gibson, C.R. (1982), Basic well log analysis for geologists; Text book, AAPG, Tulsa, Okalhoma, USA, pp. 1-239.

[3] Hasan, M.M., Akter,F.\& Deb, P.K. (2013), Formation Characterization and Identification of Potential Hydrocarbon Zone for Titas Gas Field, Bangladesh Using Wireline Log Data.International Journal of Scientific \& Engineering Research, 4(5), pp.1512-1518.

[4] Schlumberger, (1972), Log Interpretation, Volume-I-Principles; Houston, Schlumberger Well Services Inc.

[5] Atlas,D. (1979), Log Interpretation Charts; Houston, Dresser Industries. Inc. pp.107.

[6] Schlumberger, (1979), Log Interpretation Charts; English Metric, Schlumberger publication.

[7] Simandoux, P. (1963). "Mesures dielectriques en milieu poreux, application a mesure des saturations en eau, Etude du Comportment des massifs Argileux"; Revue de I'Institut Francais du Petrol, Supplementary Issue.

[8] Ahammod, S., Hai, M.A., Islam, D.M.R.\&Sayeem, S.M.A. (2014), Petro-Physical Analysis Of Reservoir Rock Of Fenchuganj Gas Field (Well\#03) Using Wireline Log.American Journal of Engineering Research (AJER), 3(8), pp.37-48.

[9] Ruhovets, N. (1990), A log analysis technique for evaluating laminated reservoir in the Gulf Coast. The log analyst, 3, pp.294-303.

[10] Fertl, W.H. (1987), Log-derived evaluation of shaly classic reservoirs.Journal of Petroleum Technology, pp.175193.https://doi.org/10.2118/14061-PA.

[11] Islam, A.R.M.T.\& Islam, M.A. (2014), Evaluation of Gas Reservoir of the Meghna Gas Field, Bangladesh Using Wireline Log Interpretation. Universal Journal of Geosciences, 2(2), pp.62-69.

[12] Eze, M.O., Mode, A.W.\& Ugbor, C.C. (2013), Formation evaluation of X7 field in the Niger Delta: evidence from Petrophysical data. Niger Delta, Nigeria. IOSR Journal of Applied Geology and Geophysics, 1 (4), pp.15 -21.https://doi.org/10.9790/0990-0141521.

[13] Amigun, J.O., Olisa, B.\& Fadeyi, O.O. (2012), Petrophysical analysis of well logs for reservoir evaluation: A case study of 'Laja' Oil Field, Niger Delta. Journal of Petroleum and Gas Exploration Research, 2(10), pp.181-187.

[14] Richardson, A.A.M. (2013), Well Correlation and Petrophysical Analysis, a Case Study of "Rickie" Field Onshore Niger Delta. The International Journal of Engineeringand Science, 2 (12), pp.94-99.

[15] Adeoti, L., Onyekachi, N., Olatinsu, O., Fatoba, J.\& Bello, M. (2014), Static Reservoir Modeling Using Well Log and 3-D Seismic Data in a KN Field, Offshore Niger Delta, Nigeria. International Journal of Geoscience, 5, pp.93-106. https://doi.org/10.4236/ijg.2014.51011.

[16] Islam, M.A., Islam, M.S., Talukder, S., Haque, K.E., Rahman, M.A.\&Ahmed, F. (2009), Petrophysical evaluation of Neogene Shaly-sand gas reservoir: A case study of Kailas Tila Gas Field; Bengal Basin, Bangladesh.International Journal of Earth Science and Engineering, 2, pp.499-511.

[17] Islam, M.A. (2010), Petrophysical evaluation of subsurface reservoir sandstone of Bengal Basin, Bangladesh.Journal Geological Societyof India, 76, pp.621-631.https://doi.org/10.1007/s12594010-0122-9. 